\title{
Effects of Caulerpa cylindracea Sonder (Chlorophyta Cauler- paceae) on marine biodiversity
}

\author{
Anna Maria Mannino' \& Paolo Balistreri \\ ${ }^{1}$ Department of Biological, Chemical and Pharmaceutical Sciences and Technologies, Section of Botany and Plant Ecology, \\ University of Palermo, Palermo, Italy \\ ${ }^{2}$ Vicolo Giotto 6, 91023 Favignana, Italy
}

\begin{abstract}
The chief purpose of Marine Protected Areas (MPAs) is biodiversity conservation. The effects that invasive alien species (IAS) have on MPAs are not yet fully known, even though assessing them is fundamental. Effective management plans, indeed, also require knowledge on the distribution, spread dynamics and impact of IAS. We report first observations on the effects of Caulerpa cylindracea Sonder (Chlorophyta Caulerpaceae) on the communities living along the coasts of the Island of Favignana (Egadi Islands MPA, Sicily, Italy). We found that $C$. cylindracea may have negative effects on the habitat where it settles in two different ways: a) affecting the structure of the native algal community which presents a low diversity, and b) favouring the settlement of other alien species such as Branchiomma bairdi (McIntosh, 1885) (Polychaeta Sabellidae).
\end{abstract}

\section{INTRODUCTION}

The Mediterranean Sea is an important hotspot for non-indigenous species (NIS, i.e. organisms introduced outside of their natural, past or present, range and outside of their natural dispersal potential). NIS may in time become invasive (i.e. invasive alien species "IAS") and may cause biodiversity loss and ecosystem service changes (Brunel et al., 2013; Giakoumi, 2014; Vergés et al., 2014, 2016). IAS are recognised as one of the most serious threats, after habitat losses, to biodiversity and natural ecosystem functioning. In the Mediterranean Sea, due to multiple human-related stressors, the number of recorded NIS has enormously increased in the last 100 years (Occhipinti-Am- brogi et al., 2011a, b; Katsanevakis et al., 2014), reaching about 1000 NIS, of which 134 species are macrophytes (Verlaque et al., 2015; Alós et al., 2016).

Among IAS, Caulerpa cylindracea Sonder 1845 (Chlorophyta Caulerpaceae) (until Belton et al., 2014 it was reported in the literature as Caulerpa racemosa var. cylindracea (Sonder) Verlaque, Huisman et Boudouresque 2003), introduced from Australia and New Caledonia (Belton et al., 2014) and reported for the first time in Italy in 1993 (in Sicily at Baia di San Panagia and at the Island of Lampedusa, Alongi et al., 1993), has raised serious concern due to its ascertained impact on Mediterranean communities (Boudouresque et al., 1995; Antolić et al., 2008; Klein \& Verlaque, 2008; 
Piazzi \& Balata, 2008; Papini et al., 2013; Katsanevakis et al., 2014).

Sicily and smaller surrounding Islands (including Marine Protected Areas "MPA"), located at the crossroads between the eastern and western sectors of the Mediterranean Sea and characterized by intense maritime traffic, are particularly vulnerable and suitable to biological marine invasions (Occhipinti-Ambrogi et al., 2011a, b; Coll et al., 2012; Papini et al., 2013; Katsanevakis et al., 2014). To plan effective management and conservation strategies, reliable data on distribution, spread dynamics and impacts of IAS are essential. For this reason, regular monitoring and surveillance programs are strongly needed. Since intensive monitoring programs could be very expensive, citizen science, involving citizens (e.g. tourists, fishermen, divers) in the collection of data, could be a useful tool for providing data on IAS that would otherwise be impossible to collect because of limitations on time and resources (Mannino \& Balistreri, 2018).

We report first observations on the effects of $C$. cylindracea on the communities living along the coasts of the Island of Favignana (Egadi Islands MPA), carried out during the citizen science project 'Caulerpa cylindracea - Egadi Islands', aimed at monitoring the spread dynamics of $C$. cylindracea within the Egadi Islands MPA.

\section{MATERIAL AND METHODS}

\section{Study area}

The Egadi Islands MPA (Aegadian Archipelago), instituted in 1991, is the largest Italian MPA. This archipelago, located approximately $7-9 \mathrm{~km}$ from the western coast of Sicily (Italy, Tyrrhenian Sea), is composed of three main islands (Favignana, Marettimo and Levanzo) and a few small islets (Galeotta, Galera, Preveto, Formica and Maraone).

The study was carried out at Cala San Giuseppe, one of the old calcarenitic opencast mine, currently submerged by the sea, located in the northern side of the Favignana Island $\left(37^{\circ} 56^{\prime} 07.00^{\prime \prime} \mathrm{N}\right.$, $12^{\circ} 20^{\prime} 02.59$ '” - Fig. 1).

\section{Sampling}

Samples were carried out in summer 2016 in two areas (Area 1, Area 2; see Fig. 1), characterized by different sedimentation and hydrodynamic conditions. The different environmental conditions are essentially linked to the presence (Area 1) or absence (Area 2) of calcarenitic blocks responsible for the reduction of the hydrodynamism and the increase of the sediment accumulation.

Within each area, two sites were selected, one characterized by a high coverage of $C$. cylindracea and the other one by the presence of a few thalli of the alga. At each site six replicated $400 \mathrm{~cm}^{2}$ quadrats were placed in order to estimate the mean abundance values of the all recorded taxa.

\section{RESULTS}

Significant differences between the two areas were observed whereas no remarkable differences were highlighted between the two sites of each area. In the area 1 , characterized by a higher rate of sedimentation, $C$. cylindracea was more abundant (a mean \% coverage of $46 \pm 8.1$ ) and behaved as a pioneer species (Fig. 2). The active mechanism of stolonisation allowed C. cylindracea to

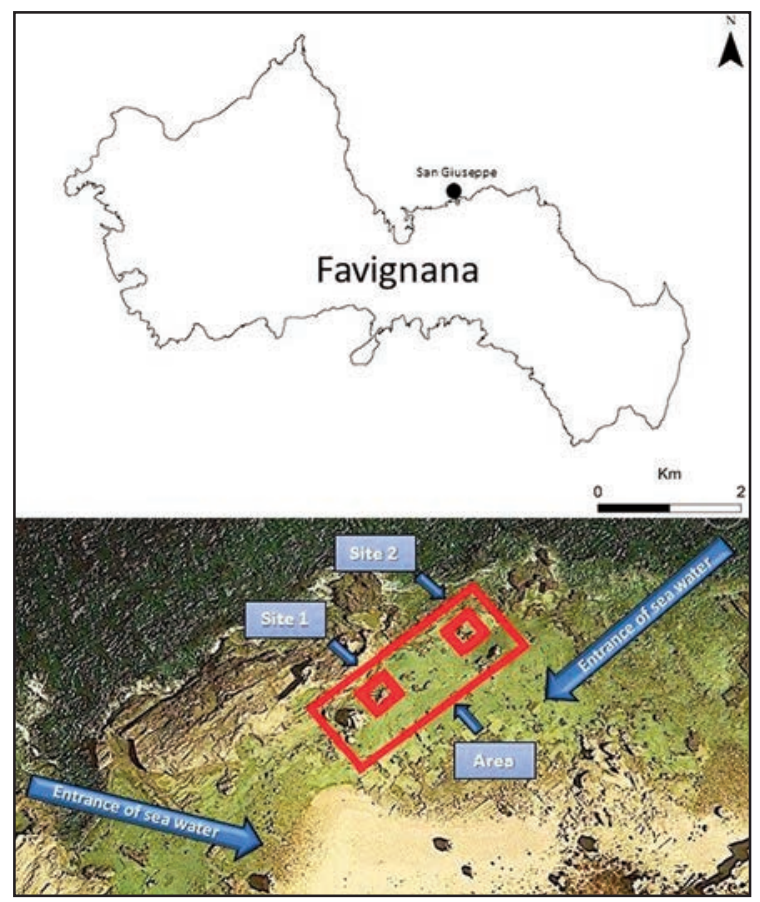

Figure 1. Map showing Cala San Giuseppe (Favignana Island, Sicily, Italy) and the sampling areas. 


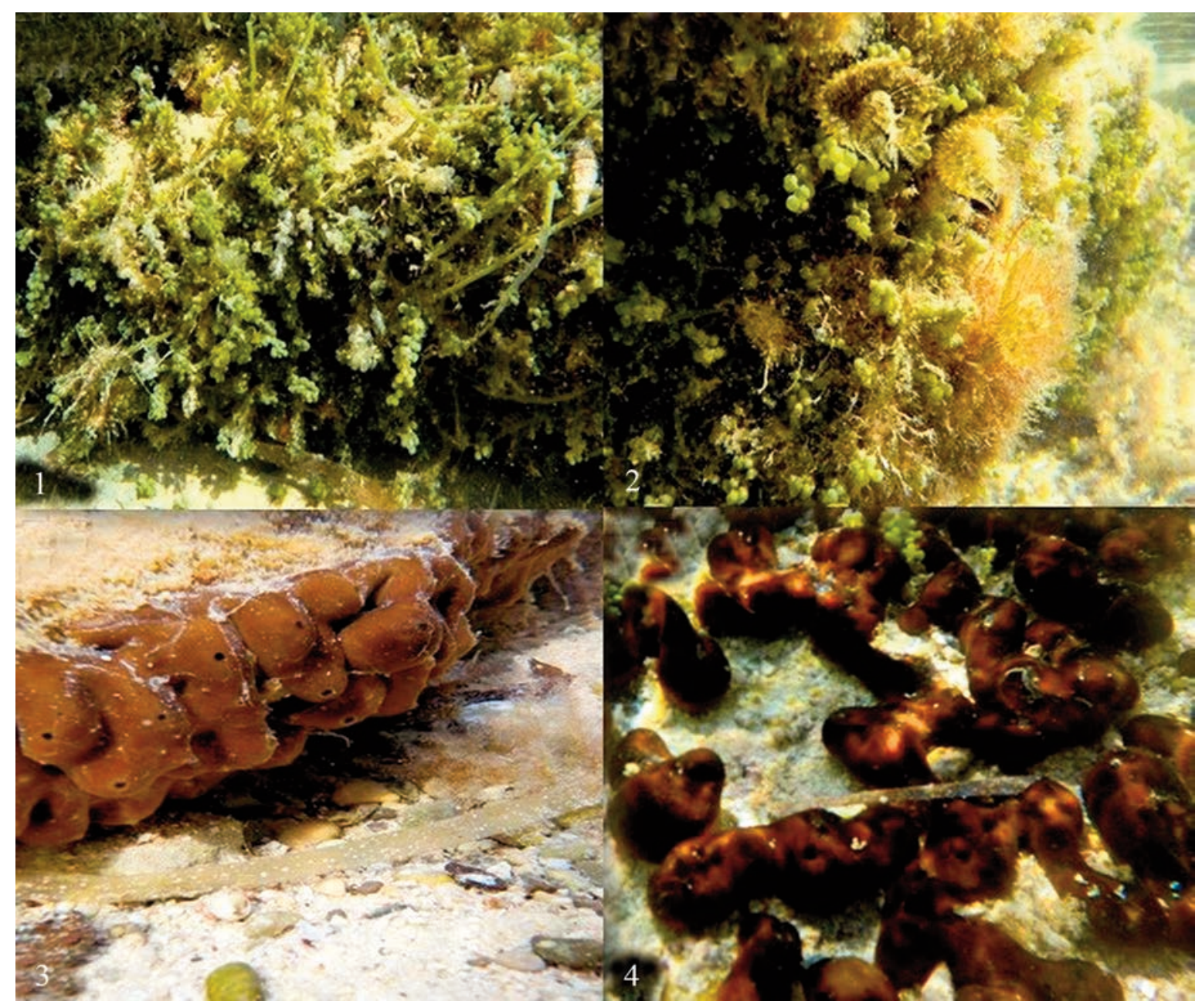

Figures 2-5. Area 1: multi-layered mats formed by Caulerpa cylindracea stolons (Fig. 2), Branchiomma bairdi among patches of C. cylindracea (Fig. 3); Area 2: the sponge Chondrilla nucula (Figs. 3, 4).

spread rapidly, forming compact multi-layered mats which trap the sediment and host native macroalgae, growing strictly intermingled to $C$. cylindracea stolons. In this area the diversity of the algal community was not particularly high (see Table 1). The algal community was essentially dominated by red and green algae such as Jania rubens (Linnaeus) J.V. Lamouroux, 1816 (Rhodophyta Corallinaceae) (a mean \% coverage of 38 \pm 6.8 ), Cladophora prolifera (Roth) Kützing, 1843 (Chlorophyta Cladophoraceae) (a mean \%

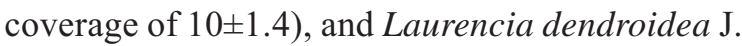
Agardh, 1852 (Rhodophyta Rhodomelaceae) (a mean $\%$ coverage of $10 \pm 4.5$ ). The mats, entrapping sediments, also favoured the establishment of another alien species, Branchiomma bairdi (McIn- tosh, 1885), a tropical tube-building sabellid polychaete, among patches of $C$. cylindracea (Fig. 3). In all 114 individuals were recorded, mainly concentrated (88 individuals) where $C$. cylindracea formed consistent mats entrapping a huge quantity of sediment.

Instead, sponges, particularly Chondrilla nucula Schmidt, 1862 (Spugna Nocciolina, a mean \% coverage of $50 \pm 4.5$ ), take advantage of the conditions in the area 2 , characterized by a low rate of sedimentation, occupying quite all the available substrate (Figs. 4, 5). In this area a few thalli of $C$. cylindracea and low coverage values of the native macroalgae were observed (see Table 2). Jania rubens (a mean \% coverage of $30 \pm 4.1$ ) was the dominant species, mainly growing as epiphyte. 


\begin{tabular}{|lc|}
\hline TAXA & COVERAGE (\%) \\
\hline Caulerpa cylindracea & $46 \pm 8.1$ \\
Jania rubens & $38 \pm 6.8$ \\
Cladophora prolifera & $10 \pm 1.4$ \\
Laurencia dendroidea & $10 \pm 4.5$ \\
Anadyomene stellata & $5 \pm 1.5$ \\
Lychaete pellucida & $5 \pm 1.7$ \\
Dictyota dichotoma & $1 \pm 0.8$ \\
Flabellia petiolata & $1 \pm 0.7$ \\
Padina pavonica & $1 \pm 0.5$ \\
\hline
\end{tabular}

Table 1. Area 1: coverage values (mean $\pm \mathrm{SE}, \mathrm{n}=6$ ) of Caulerpa cylindracea and the native macroalgae.

\begin{tabular}{|lc|}
\hline TAXA & COVERAGE (\%) \\
\hline Chondrilla nucula & $50 \pm 4.5$ \\
Jania rubens & $30 \pm 4.1$ \\
Laurencia dendroidea & $5 \pm 0.6$ \\
Caulerpa cylindracea & $2 \pm 0.8$ \\
Padina pavonica & $1 \pm 0.5$ \\
\hline
\end{tabular}

Table 2. Area 2: coverage values (mean $\pm \mathrm{SE}, \mathrm{n}=6$ ) of Chondrilla nucula, Caulerpa cylindracea and the native macroalgae.

\section{DISCUSSION AND CONCLUSIONS}

First results showed how the rate of sedimentation has an important role in structuring the communities in the studied areas. In the area 1 we assisted to a cascade process. Precisely, the high rate of sedimentation favoured the growth and spread of C. cylindracea which in turn allowed a further increase of sedimentation, as consequence of the multi-layered mats trapping the sediment, which favoured the establishment of several individuals of Branchiomma bairdi among the patches of $C$. cylindracea. This biofouler worm, already recorded at the Egadi Island MPA (Mytilineou et al., 2016), clearly takes advantage of the additional debris among the stolons of $C$. cylindracea, on which it can easily settle. Even though this worm was originally described from Bermuda and Caribbean Sea (western Atlantic), its origin is currently unknown (Ramalhosa et al., 2014).

In the area 2, instead, where the rate of sedimentation is low, sponges such as Chondrilla nucula, take advantage behaving as pioneer species and they also maintain low both the rate of sedimentation and the biodiversity. Indeed, they do not allow algal species, $C$. cylindracea included, to settle well in the area, as clearly shown by the low coverage values observed for $C$. cylindracea and the native macroalgae. The low rate of sedimentation does not allow also the settlement of Branchiomma bairdi individuals, which do not find suitable environment conditions for their establishment. Therefore, C. cylindracea may have negative effects on the habitat where it settles in two different ways: a) affecting the structure of the native algal community which presents a low diversity, and b) favouring the settlement of other alien species. It was already observed by Baldacconi \& Corriero (2009) how C. cylindracea (reported as C. racemosa var. cylindracea) may significantly affect the percentage cover of sponge assemblage of coralligenous concretions, likely due to the ability of $C$. cylindracea to overgrow several sponge species.

Since Sicily and the circum-Sicilian Islands, are vulnerable to biological marine invasions, regular monitoring programs are needed to assess the spread dynamics of invasive species, particularly in MPAs such as Egadi islands MPA. In the MPAs, high rates of visitation could promote the introduction of invasive species through increased disturbance and vectors (e.g., boat anchors, SCUBA equipment, hull fouling) and subsequent dispersal of propagules (Britton-Simmons \& Abbott, 2008; Burfeind et al., 2013), therefore an IAS strategy integrated into the management plan of the Egadi Islands MPA may be highly desirable. 


\section{REFERENCES}

Alongi G., Cormaci M., Furnari G. \& Giaccone G., 1993. Prima Segnalazione di Caulerpa racemosa (Chlorophyceae, Caulerpales) per le Coste Italiane. Bollettino Accademia Gioenia Scienze Naturali Catania, 26: 9-53.

Alós J., Tomas F., Terrados J., Verbruggen H. \& Ballesteros E., 2016. Fast-Spreading Green Beds of Recently Introduced Halimeda incrassata Invade Mallorca Island (NW Mediterranean Sea). Marine Ecology Progress Series, 558: 153-158. https://doi. org/10.3354/meps 11869

Antolić B., Zuljević A., Despalatović M., Grubelić I. \& Cvitković I., 2008. Impact of the invasive green alga Caulerpa racemosa var. cylindracea on the epiphytic macroalgal assemblage of Posidonia oceanica seagrass rhizomes in the Adriatic Sea. Nova Hedwigia, 86: 155-167. https://doi.org/10.1007/s10530-0110043-6

Baldacconi R. \& Corriero G., 2009. Effects of the spread of the alga Caulerpa racemosa var. cylindracea on the sponge assemblage from Coralligenous concretions of the Apulian coast (Ionian Sea, Italy). Marine Ecology, 30: 337-345. https://doi.org/10.1111/j.14390485.2009.00282.x

Belton G.S., Prud'homme van Reine W.F., Huisman J.M., Draisma S.G.A. \& Gurgel C.F.D., 2014. Resolving phenotypic plasticity and species designation in the morphologically challenging Caulerpa racemosapeltate complex (Chlorophyta, Caulerpaceae). Journal of Phycology, 50: 32-54. https://doi.org/10.1111/ jpy.12132. Epub 2013 Dec 31.

Boudouresque C.F., Meinesz A., Ribera M.A. \& Ballesteros E., 1995. Spread of the green alga Caulerpa taxifolia (Caulerpales, Chlorophyta) in the Mediterranean: Possible consequences of a major ecological event. Scientia Marina, 59: 21-29.

Britton-Simmons K.H. \& Abbott K.C., 2008. Short- and long-term effects of disturbance and propagule pressure on a biological invasion. Journal of Ecology, 96: 68-77. https://doi.org/10.1111/j.1365-2745.2007.01 319.x

Brunel S., Fernández-Galiano E., Genovesi P., Heywood V.H., Kueffer C. \& Richardson D.M. 2013. Invasive Alien Species: A Growing but Neglected reat? In Late Lessons from Early Warning: Science, Precaution, Innovation. Lessons for Preventing Harm. EEA Report 1/2013, Copenhagen, pp. 518-540.

Burfeind D.D., Pitt K.A., Connolly R.M. \& Byers J.E., 2013. Performance of Invasive Species within Marine Reserves. Biological Invasions, 15: 17-28. https:// doi.org/10.1007/s10530-012-0265-2

Coll M., Piroddi C., Albouy C., Ben Rais Lasram F., Cheung W.W.L., Christensen V., Karpouzi V.S., Guilhaumon F., Mouillot D., Paleczny M., Palomares
M.L., Steenbeek J., Trujillo P., Watson R. \& Pauly D., 2012. The Mediterranean Sea under siege: spatial overlap between marine biodiversity, cumulative threats and marine reserve. Global Ecology and Biogeography, 21: 465-480. https://doi.org/10.1111/ j1466-8238.2011.00697.x

Giakoumi S., 2014. Distribution Patterns of the Invasive Herbivore Siganus luridus (Rüppell, 1829) and its Relation to Native Benthic Communities in the Central Aegean Sea, Northeastern Mediterranean. Marine Ecology, 35: 96-105. https://doi.org/110.1111/maec. 12059

Katsanevakis S., Coll M., Piroddi C., Steenbeek J., Ben Rais Lasram F., Zenetos A. \& Cardoso A.C., 2014. Invading the Mediterranean Sea: biodiversity patterns shaped by human activities. Frontiers in Marine Science,1:32. https://doi.org/3389/fmars.2014.00032.

Klein J. \& Verlaque M., 2008. The Caulerpa racemosa invasion: a critical review. Marine Pollution Bulletin, 56: 205-225. https://doi.org/110.1016/j.marpolbul. 2007.09.043

Mannino A.M. \& Balistreri P., 2018. Citizen science: a successful ttool for monitoring invasive alien species (IAS) in Marine Protected Areas. The case study of the Egadi Islands MPA (Tyrrhenian Sea, Italy). Biodiversity, 19: 42-48. https://doi.org/10.1080/1488 8386.2018.1468280

Mytilineou C., Akel E., Babali N., Balistreri P., Bariche M., Boyaci Y., Cilenti L., Constantinou C., Crocetta F., Çelik M., Dereli H., Dounas C., Durucan F., Garrido A., Gerovasileiou V., Kapiris K., Kebapcioglu T., Kleitou P., Krystalas A., Lipej L., Maina I., Marakis P., Mavrič B., Moussa R., Peña-Riva, L., Poursanidis D., Renda W., Rizkalla S., Rosso A., Scirocco T., Sciuto F., Servello G., Tiralongo F., Yapici S., \& Zenetos A., 2016. New Mediterranean Biodiversity Records (November, 2016). Mediterranean Marine Science, 17: 794-821. http://dx.doi. org $/ 10.12681 / \mathrm{mms} .1976$

Occhipinti-Ambrogi A., Marchini A., Cantone G., Castelli A., Chimenz C., Cormaci M., Froglia C., Furnari G., Gambi M.C., Giaccone G., Giangrande A., Gravili C., Mastrototaro F., Mazziotti C., OrsiRelini L. \& Piraino S., 2011a. Alien species along the Italian coasts: an overview. Biological Invasions, 13: 215-237. https://doi.org/110.1007/s10530-010-9803y

Occhipinti-Ambrogi A., Marchini A., Cantone G., Castelli A., Chimenz C., Cormaci M., Froglia C., Furnari G., Gambi M.C., Giaccone G., Giangrande A., Gravili C., Mastrototaro F., Mazziotti C., OrsiRelini L. \& Piraino S., 2011b. Erratum to: alien species along the Italian coasts: an overview. Biological Invasions, 13: 531-532. https://doi.org/10.1007/ s10530-010-9856-y 
Papini A., Mosti S. \& Santosuosso U., 2013. Tracking the origin of the invading Caulerpa (Caulerpales, Chlorophyta) with Geographic Profiling, a criminological technique for a killer alga. Biological Invasions, 15: 1613-1621. https://doi.org/10.1007/s105 30-012-0396-5

Piazzi L. \& Balata D., 2008. The spread of Caulerpa racemosa var. cylindracea in the Mediterranean Sea: an example of how biological invasions can influence beta diversity. Marine Environmental Research, 65: 50-61. https://doi.org/10.1016/j.marenvres.2007.07. 002

Ramalhosa P., Camacho-Cruz K., Bastida-Zavala R. \& Canning-Clode J., 2014. First record of Branchiomma bairdi McIntosh, 1885 (Annelida: Sabellidae) from Madeira Island, Portugal (northeastern Atlantic Ocean). BioInvasions Records, 3: 235-239. https://doi.org/10.3391/bir.2014.3.4.04

Vergés A., Steinberg P.D., Hay M.E., Poore A.G., Campbell A.H., Ballesteros E., Heck K.L. Jr., Booth D.J., Coleman M.A., Feary D.A., Figueira W., Langlois T.,
Marzinelli E.M., Mizerek T., Mumby P.J., Nakamura Y., Roughan M., van Sebille E., Gupta A.S., Smale D.A., Tomas F., Wernberg T. \& Wilson S.K., 2014. The Tropicalization of Temperate Marine Ecosystems: Climate-Mediated Changes in Herbivory and Community Phase Shifts. Proceedings Biological Sciences, 281: 20140846. https://doi.org/10.1098/ rspb.2014.0846.

Vergés A., Doropoulos C., Malcolm H.A., Skye M., Garcia-Pizá M., Marzinelli E.M., Campbell A.H., Ballesteros E., Hoey AS., Vila-Concejo A., Bozec Y.M., Steinberg P.D., 2016. Long-Term Empirical Evidence of Ocean Warming Leading to Tropicalization of Fish Communities, Increased Herbivory, and Loss of Kelp. Proceedings of the National Academy of Sciences U.S.A., 113: 13791-13796.

Verlaque M., Ruitton S., Mineur F. \& Boudouresque C.F., 2015. Vol. 4, Macrophytes. In: Briand F., CIESM Atlas of Exotic Species in the Mediterranean. CIESM Publ., Monaco, 1-364. 